\title{
WYBÓR I PRZYGOTOWANIE REJESTRACJI ZDARZEŃ SEJSMICZNYCH DO MODELOWANIA NUMERYCZNEGO REAKCJI ZAPÓR ZIEMNYCH OBCIĄŻONYCH SEJSMICZNIE
}

\author{
Aleksandra Korzec ${ }^{\bowtie}$, Waldemar Świdziński \\ Instytut Budownictwa Wodnego PAN, Gdańsk
}

\begin{abstract}
STRESZCZENIE
W artykule przedstawiono kryteria wyboru akcelerogramów obliczeniowych modelujących obciążenie sejsmiczne w analizie stateczności zapór ziemnych. Kryteria te uzupełniono o kryterium intensywności Ariasa, które pozwala wskazać akcelerogram dający największe wartości przemieszczeń trwałych zapory skumulowanych podczas trzęsienia ziemi. Wykazano również, że dla akcelerogramów o zbliżonej intensywności Ariasa rozstrzygającym kryterium jest szczytowa wartość prędkości wymuszenia sejsmicznego. Wiele uwagi poświęcono też niezbędnym modyfikacjom zarejestrowanych przebiegów przyspieszeń, które zapewnią przeprowadzenie wiarygodnej oceny stateczności. Wykazano znaczący wpływ szumów zawartych w akcelerogramie na wyznaczane przebiegi prędkości i przemieszczeń, a tym samym na parametry tych przebiegów i wyniki obliczeń. Ponadto przeanalizowano wpływ dekonwolucji akcelerogramu na ocenę stateczności zapory ziemnej.
\end{abstract}

Słowa kluczowe: analizy dynamiczne, trzęsienia ziemi, akcelerogram, stateczność, dekonwolucja, analiza sygnału

\section{WSTĘP}

Oprócz obciążeń o charakterze statycznym, wywołanych w głównej mierze ciężarem własnym, zapory ziemne mogą być również narażone na działanie obciążeń dynamicznych. Obciążenia te mogą być spowodowane zjawiskami naturalnymi, takimi jak trzęsienia ziemi (najczęściej wywołane wzajemnymi ruchami mas skalnych wzdłuż uskoków tektonicznych), zapadliska krasowe lub gwałtowne osuwiska powierzchniowe (Lowrie, 2007). Obciążenia dynamiczne mogą być też wynikiem działalności człowieka, spośród których najniebezpieczniejsze dla masywnych budowli ziemnych są tzw. wstrząsy parasejsmiczne, które mogą mieć skalę słabych naturalnych trzęsień ziemi. Spowodowane są one odprężeniem górotworu w pobliżu wyrobisk górniczych prowadzonych w rejonie zaburzeń tektonicznych (rys. 1).

Wielkość trzęsienia ziemi najczęściej charakteryzowana jest parametrem nazywanym magnitudą, który w przybliżeniu określa ilość energii wyzwalanej w trakcie wstrząsu i przenoszonej przez fale sejsmiczne. Zwyczajowo magnitudę podaje się w logarytmicznej skali Richtera (opracowanej w 1935 r.), choć obecnie stosuje się inne, nowsze metody jej wyznaczania (Srbulov, 2008). Magnitudy przykładowych trzęsień ziemi odczuwalnych w Polsce nie przekroczyły 5 (Podhale 2004 - 4,7; Polkowice 1977 - 4,5). Dla porównania, silne trzęsienia ziemi z 2011 r., którego epicentrum znajdowało się u wybrzeży Japonii, miało magnitudę równą 8,9 (Tôhoku, Honsiu, Japonia).

凶a.korzec@ibwpan.gda.pl 


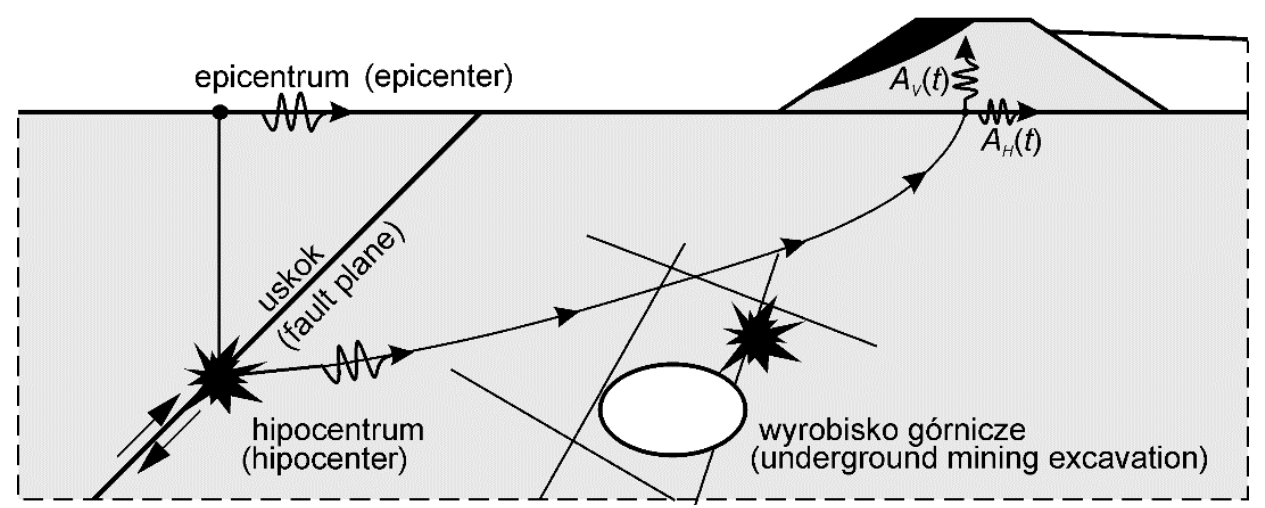

Rys. 1. Obciążenia sejsmiczne działające na budowle ziemne

Fig. 1. Seismic loadings acting on earth structures

Jednak najpełniejszym źródłem informacji o trzęsieniu ziemi, które pozwoli uwzględnić jego wpływ na obiekty budowlane, są zapisy przyspieszeń ziemi w czasie trwania wstrząsu - $A(t)$, nazywane akcelerogramami. Wynika to z bezpośredniego związku przyspieszeń z siłami bezwładności działającymi na zagrożony obiekt. Pomiary przyspieszeń $\mathrm{w}$ trzech prostopadłych do siebie kierunkach wykonywane są przez stacje sejsmiczne połączone $\mathrm{w}$ krajowe sieci sejsmiczne, których przykładami są: japońska K-net, włoska ITACA czy polska PD. Poza krajowymi bazami silnych wstrząsów istnieje wiele ogólnodostępnych internetowych baz danych, w których gromadzone są informacje dla większych regionów, czego przykładem może być europejska baza European Strong-motion Database-ESD, która zgromadziła 2213 sygnałów (Ambraseys i in., 2004). Na podstawie gromadzonych akcelerogramów wraz z informacjami charakteryzującymi zarówno zdarzenie sejsmiczne, jak i stację sejsmiczną wykonywane są mapy ryzyka sejsmicznego, prognozujące wartości przyspieszenia, które z określonym prawdopodobieństwem zostaną przekroczone w czasie życia obiektu. W przypadku braku pomiarów z lokalizacji projektowanego obiektu bazy te stanowią również źródło danych dla przyjęcia warunku brzegowego w obliczeniach stateczności zapór ziemnych prowadzonych metodą uproszczoną Newmarka lub tzw. pełną metodą dynamiczną (Kramer, 1996; Świdziński i Korzec, 2015).

Celem niniejszej pracy jest wskazanie parametrów charakteryzujących akcelerogram mogących stanowić kryterium wyboru obciążeń sejsmicznych, dla których uzyska się wiarygodną ocenę stateczności zapory ziemnej. Dodatkowym celem jest wskazanie niezbędnych modyfikacji kinematycznego warunku brzegowego wpływających na poprawność przeprowadzanych obliczeń.

\section{CHARAKTERYSTYKA WYMUSZENIA DYNAMICZNEGO}

Wymuszenie sejsmiczne najczęściej jest charakteryzowane poprzez szczytową wartość przyspieszenia - PGA (ang. peak ground acceleration), czyli maksymalną wartość bezwzględną przebiegu czasowego przyspieszenia $-A(t)$ (rys. 2). Szczytowe wartości przyspieszeń poziomych PHA (ang. peak horizontal acceleration) zmierzonych podczas silnych trzęsień ziemi osiągają 0,5 $g$ i więcej ( $g$ oznacza przyspieszenie ziemskie). Maksymalna zmierzona wartość $\mathrm{PHA}_{10}$ w rejonie $\mathrm{LGOM}^{1}$ była równa $0,183 \mathrm{~g}$ (Jamiolkowski i in., 2010). Prawidłowo podana wartość $P G A$, zwłaszcza w przypadku wstrząsów parasejsmicznych, powinna zawierać informację dotyczącą

\footnotetext{
${ }^{1}$ Legnicko-Głogowski Okręg Miedziowy.
} 


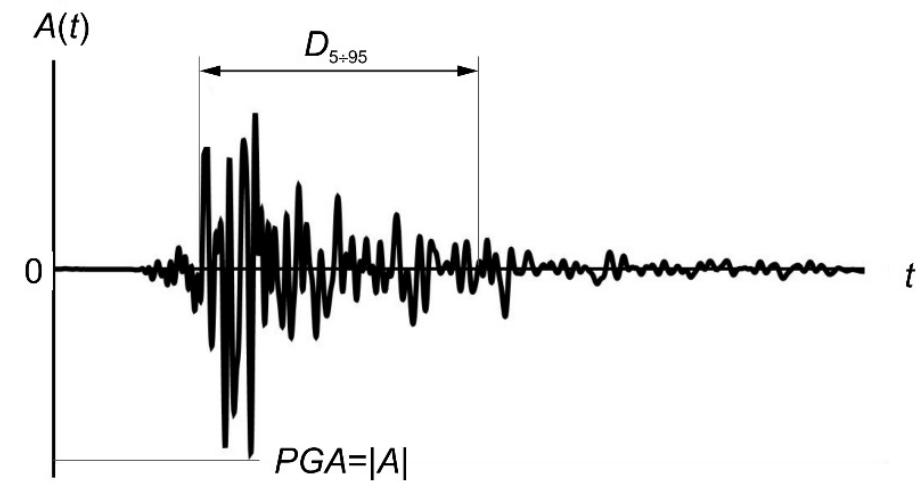

Rys. 2. Definicja szczytowej wartości przyspieszenia $P G A$

Fig. 2. Definition of peak ground acceleration $P G A$

górnego zakresu częstotliwości sygnału, np. przez podanie go w indeksie dolnym $-P G A_{10}$.

Szczytowa wartość przyspieszenia $P G A$ nie jest jednak wystarczającym parametrem, który pozwala opisać skutki działania trzęsienia ziemi na zaporę ziemną. Z uwagi na widmo amplitudowe akcelerogramu, które odpowiada za ilość energii niesionej przez sygnał, sygnały o tej samej wartości $P G A$ mogą wywierać różny wpływ na obiekty budowlane. Analiza amplitud Fouriera - $|\mathrm{F}|$ - dla poszczególnych składowych harmonicznych pozwala na wskazanie dominującej częstotliwości sygnału $f_{1}$ (rys. 3) lub zakresu dominujących częstotliwości i jej ewentualnej zgodności z częstotliwością rezonansową obiektu, która skutkować będzie jego maksymalną odpowiedzią na wymuszenie sejsmiczne. Dominujące częstotliwości trzęsień ziemi wynoszą 2-3 Hz, a wstrząsy parasej- smiczne charakteryzują się wyższymi dominującymi częstotliwościami, równymi 3-5 Hz.

Wiele badań wskazuje, że szczytowa wartość prędkości wymuszenia sejsmicznego $P G V$ (ang. peak ground velocity) w lepszy sposób niż $P G A$ charakteryzuje potencjalne skutki wstrząsu dla obiektów budowlanych (Zembaty, 2004). Innym parametrem opisującym wymuszenie sejsmiczne, który pośrednio zawiera w sobie informację o widmie amplitudowym, jest intensywność Ariasa $-I_{a}$ (ang. Arias intensity), definiowana wzorem (Arias, 1970):

$$
I_{a}=\frac{\pi}{2 \mathrm{~g}} \cdot \int A(t)^{2} \mathrm{~d} t
$$

Intensywność Ariasa przedstawiana jest również w postaci jej procentowej zmiany w czasie (rys. 4). $\mathrm{Na}$

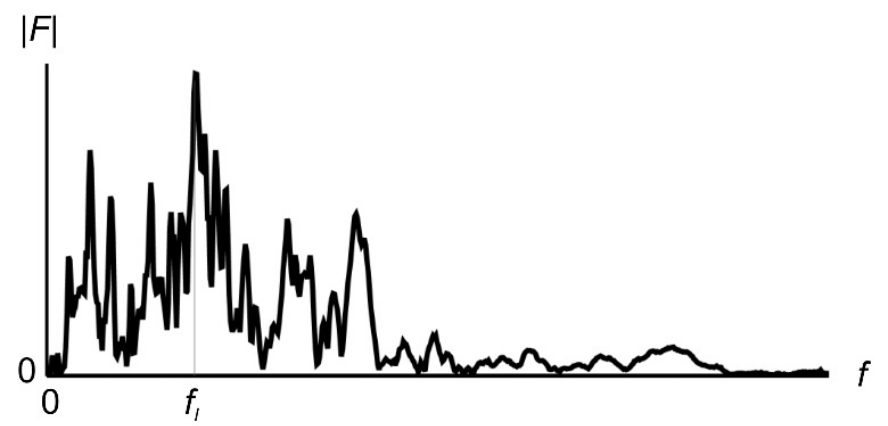

Rys. 3. Widmo akcelerogramu z rysunku 2

Fig. 3. Spectrum of acceleration form Figure 2 


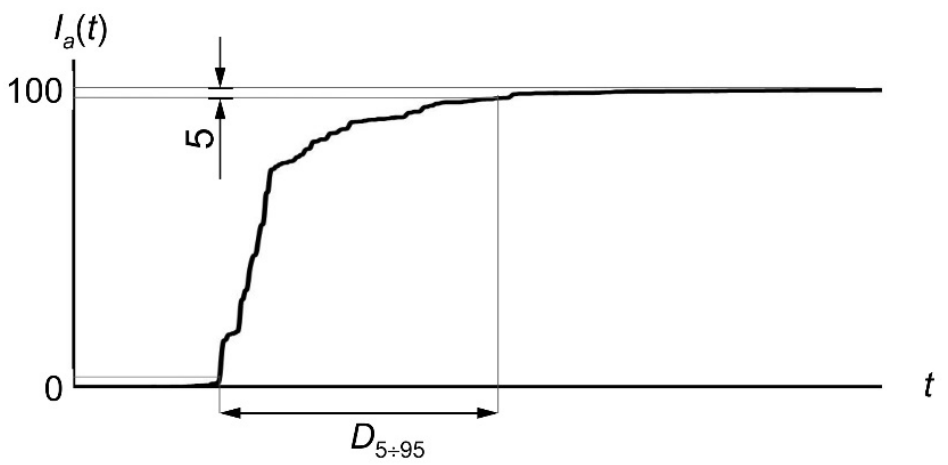

Rys. 4. Zmiana intensywności Ariasa $\left(I_{a}\right)$ w czasie oraz definicja czasu trwania wstrząsu $\left(D_{5 \div 95}\right)$ według Trifunaca i Brady'ego (1975)

Fig. 4. Normalized Arias intensity plot and definition of Trifunac and Brady's (1975) duration of strong motion

bazie tej zmienności Trifunac i Brady (1975) wprowadzili definicję czasu trwania intensywnej fazy wstrząsu $\left(D_{5 \div 95}\right)$, wyznaczanej przedziałem czasu, który zawiera $90 \%$ energii niesionej przez sygnał (por. rys. 2). Powyższa miara stosowana jest jako kryterium wyboru akcelerogramu do analizy, a także w celu wyboru do obliczeń istotnego fragmentu sygnału, co pozwala na skrócenie czasu obliczeń.

Obciążenie dynamiczne często charakteryzowane jest również przez widma odpowiedzi zmiennych ruchu (przyspieszeń, prędkości i przemieszczeń) układu dynamicznego o jednym stopniu swobody z założonym współczynnikiem thumienia. Spektrum odpowiedzi na akcelerogram przedstawiony na rysunku 2 porównane z wzorcowym (wg EC8) spektrum sprężystym odpowiedzi typu 2 dla podłoża typu B pokazano na rysunku 5 .

\section{WYBÓR AKCELEROGRAMÓW OBLICZENIOWYCH}

Losowy charakter trzęsień ziemi w analizach stateczności uwzględniony jest poprzez przeprowadzenie obliczeń dla kilku wymuszeń sejsmicznych. Według zaleceń zawartych w Eurokodzie 8 (EC8, 2005) obliczenia należy przeprowadzić dla co najmniej 3 stochastycznych, niezależnych przebiegów czasowych przyspieszenia o różnej strukturze częstotliwościowej

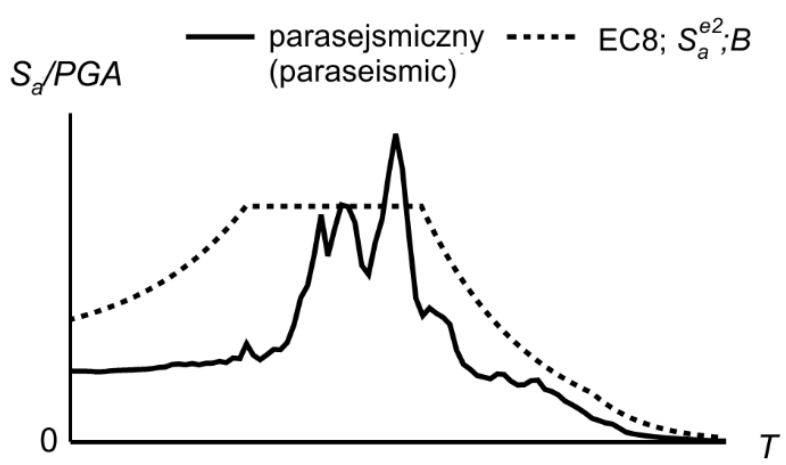

Rys. 5. Przyspieszeniowe spektrum odpowiedzi na sygnał z rysunku 2 porównane z wzorcowym (wg EC8) sprężystym spektrum odpowiedzi typu 2 dla podłoża typu B (współczynnik tłumienia 5\%)

Fig. 5. Acceleration response spectrum from the signal presented in Figure 2 compared to EC 8 type 2 elastic spectrum for B ground type (5\% damping) 
Korzec, A., Świdziński, W. (2018). Wybór i przygotowanie rejestracji zdarzeń sejsmicznych do modelowania numerycznego reakcji zapór ziemnych obciążonych sejsmicznie. Acta Sci. Pol. Architectura, 17 (2), 53-63. doi: 10.22630/ASPA.2018.17.2.14

i długości trwania intensywnej fazy wstrząsu. Ocena stateczności dokonywana jest na podstawie maksymalnej reakcji obiektu. W literaturze tematu spotkać można jednak także propozycje przeprowadzanie obliczeń dla co najmniej 7 , a nawet 10 przebiegów czasowych przyspieszań, tak aby otrzymać stabilną średnią reakcję obiektu, która poddawana jest ocenie (Bommer i Acevedo, 2004).

Ogólne wytyczne dotyczące wyboru akcelerogramów obliczeniowych zawarto w Eurokodzie 8 oraz w Biuletynie 148 wydanym przez Międzynarodową Komisję ds. Wielkich Zapór (ICOLD $\left.{ }^{2}, 2016\right)$. Szczegółowe wytyczne, np. dotyczące różnicy czasu trwania analizowanych akcelerogramów, zawarte są w załącznikach krajowych.

Pierwszej preselekcji dostępnych sygnałów należy dokonać według zgodności z prognozowanymi parametrami wstrząsu. Zaleca się przede wszystkim, aby różnica magnitud zdarzeń sejsmicznych, których rejestracje wybrano, nie przekraczała 0,25 . Współczynnik skalowania wybranych akcelerometrów do prognozowanej szczytowej wartości przyspieszeń nie powinien być większy od 2 (lub mniejszy od odwrotności 2). Listę akcelerogramów można zawęzić, stosując kryterium prawdopodobnej odległości od epicentrum wstrząsu. Często to właśnie przyjęty zakres odległości stacji sejsmicznej od epicentrum wstrząsu pozwala na wybranie wstrząsów charakteryzujących się różnym czasem trwania. Bazy danych oferują wiele innych parametrów, które mogą stanowić istotne kryterium wyboru akcelerogramów, m.in. klasyfikację podłoża, ukształtowanie terenu czy mechanizm powstania wstrząsu. Niestety, z uwagi na niepełne informacje o wszystkich zdarzeniach sejsmicznych, stosowanie tych kryteriów nie jest zalecane.

W Eurokodzie 8 zawarto również zalecenie zgodności spektrów odpowiedzi układu dynamicznego o jednym stopniu swobody na wybrane akcelerogramy z wzorcowym spektrum odpowiedzi, zwłaszcza w przedziale $0,2 T_{1}$ do $T_{1}$, gdzie $T_{1}$ oznacza podstawowy okres drgań własnych obiektu. Jest to szeroka tematyka, której nie podjęto szczegółowo w niniejszym artykule.

Przed podjęciem ostatecznego wyboru należy zadbać o to, aby wybrane sygnały nie pochodziły $z$ tej samej stacji sejsmicznej, chyba że znajduje się ona w miejscu projektowanego obiektu. Wybrane sygnały nie powinny być także rejestracją tego samego zdarzenia sejsmicznego.

Pewnego komentarza wymaga również wybór składowej poziomej przyspieszenia. Najczęściej do obliczeń przyjmowany jest przebieg przyspieszeń poziomych o większej wartości szczytowej. Autorzy sugerują jednak wybór akcelerogramu charakteryzujący się większą intensywnością Ariasa. W przypadku uwzględnienia w obliczeniach stateczności składowej pionowej przyspieszenia żadne z powyższych podejść nie gwarantuje analizy najniekorzystniejszego przypadku (Korzec, 2016) i obliczenia należy przeprowadzać dla dwóch kombinacji obciążenia.

\section{MODYFIKACJA ZAREJESTROWANYCH AKCELEROGRAMÓW}

W bazach danych gromadzone są z reguły rejestracje silnych wstrząsów w wersji oryginalnej zawierające szumy krótko- i długookresowe wynikające m.in. $\mathrm{z}$ dokładności aparatury pomiarowej, sposobu przesyłu danych czy np. z tego, że w pobliżu akcelerometru prowadzono prace budowlane (Boore i Bommer, 2005). Usuwanie wyraźnego trendu $\mathrm{z}$ akcelerogramu dotyczy przede wszystkim digitalizowanych zapisów historycznych trzęsień ziemi. Niemniej jednak wystąpienie trendu nawet o niewielkiej wartości powoduje, że wyznaczane metodą całkowania numerycznego prędkości i przemieszczenia są niefizyczne (nie mają charakteru ruchu harmonicznego w czasie), a tym samym wyznaczone parametry wymuszenia sejsmicznego nie są poprawne. Warunkiem koniecznym przeprowadzenia poprawnych obliczeń numerycznych jest stosowanie takich przebiegów przyspieszeń, które skutkują zerową prędkością na koniec wymuszenia dynamicznego. $\mathrm{W}$ przypadku przebiegu przemieszczeń, z uwagi na brak pomiarów przemieszczeń metodą geodezyjną, możliwa jest jedynie jakościowa ocena, czy ma on charakter thumionego ruchu oscylacyjnego.

W celu wyeliminowania szumów można zastosować filtr pasmowo-przepustowy (ang. band pass filter) będący szeregowym połączeniem filtru górno-

\footnotetext{
${ }^{2}$ The International Commission on Large Dams.
} 
i dolnoprzepustowego, który „wycina” z sygnału wszystkie fale o częstotliwości poniżej i powyżej zadanych wartości granicznych $\left(f_{G} \mathrm{i} f_{D}\right)$ - rysunek 6 . Do obróbki sygnałów pobranych z baz danych najczęściej stosowane są wartości graniczne częstotliwości $f_{0 G}=0,25 \mathrm{~Hz}$ oraz $f_{0 D}=25 \mathrm{~Hz}$ (Ambraseys i in., 2004). Częstotliwość graniczna $\left(f_{0 D}\right)$ wynika z największego wpływu tego zakresu częstotliwości na konstrukcje budowlane. Najczęściej stosuje się filtr eliptyczny lub filtr Butterwortha. $Z$ doświadczeń autorów wynika, że przeprowadzenie filtracji sygnału nie zawsze pozwala uzyskać oscylacyjną postać przebiegów prędkości i przemieszczeń.
Drugą z metod służących do usuwania szumów długookresowych $\mathrm{z}$ sygnału jest eliminacja trendu sygnału opisanego wielomianem, którego współczynniki są obliczane na podstawie aproksymacji metodą najmniejszych kwadratów (rys. 7).

$\mathrm{Z}$ uwagi na ograniczenie czasu obliczeń numerycznych celowe jest wykonanie modelu dyskretnego dostosowanego do zakresu częstotliwości fal istotnych z punktu widzenia maksymalnej odpowiedzi dynamicznej analizowanego obiektu. W przypadku zapór ziemnych, których okresy drgań własnych zawieraja się w zakresie od 0,5 do $1,5 \mathrm{~s}$ (ICOLD, 2016), przyjmuje się, że wystarczające jest ograni-

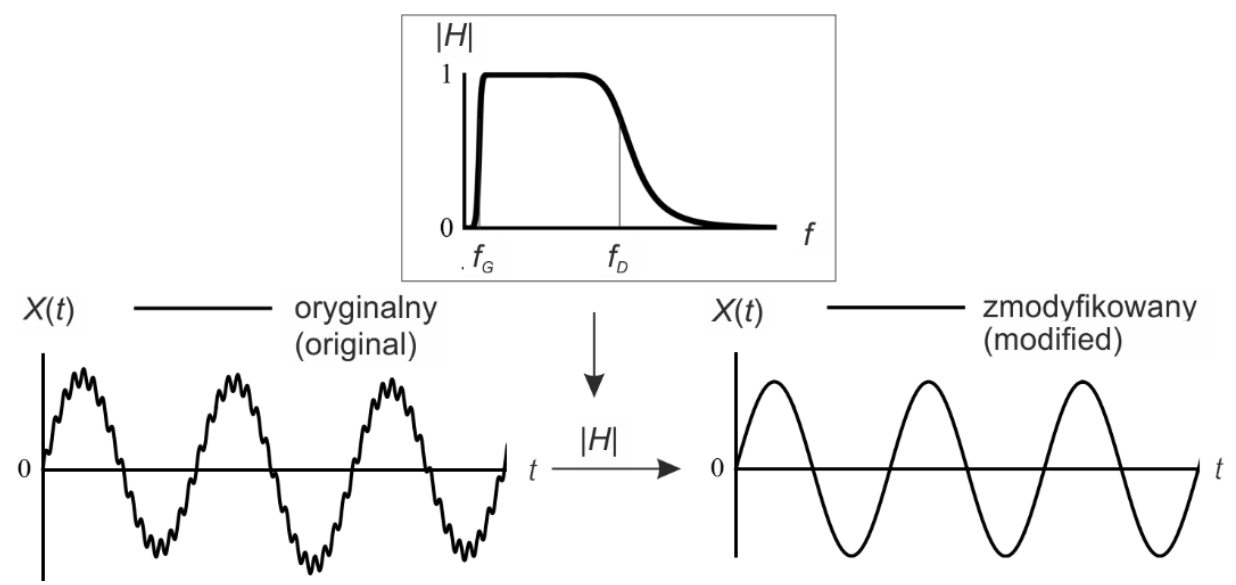

Rys. 6. Redukcja szumu z przebiegu czasowego pasmowo-przepustowym filtrem Butterwortha

Fig. 6. Elimination of noise from the signal using Butterworth band-pass filter

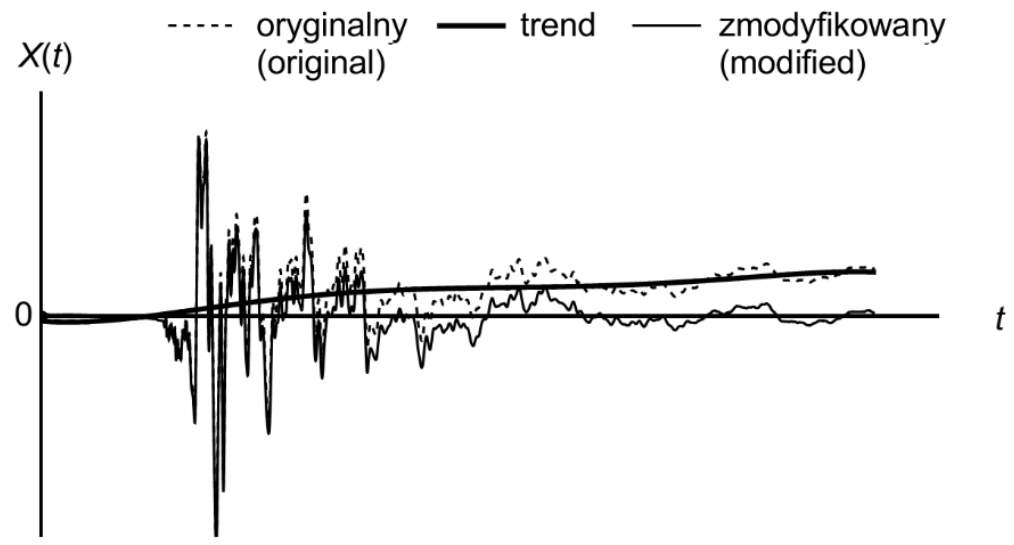

Rys. 7. Redukcja szumu długookresowego z przebiegu czasowego metodą eliminacji trendu

Fig. 7. Reduction of long-period noise by baseline adjustment method 
Korzec, A., Świdziński, W. (2018). Wybór i przygotowanie rejestracji zdarzeń sejsmicznych do modelowania numerycznego reakcji zapór ziemnych obciążonych sejsmicznie. Acta Sci. Pol. Architectura, 17 (2), 53-63. doi: 10.22630/ASPA.2018.17.2.14

czenie częstotliwości wprowadzanych do modelu fal do $10 \mathrm{~Hz}$. Konieczna jest wówczas modyfikacja sygnału, którą wykonuje się poprzez zastosowanie filtra dolnoprzepustowego.

W przypadku przeprowadzania analiz do celów projektowych konieczne jest przeskalowanie wybranych akcelerogramów, tak aby szczytowe wartości przyspieszenia były zgodne $\mathrm{z}$ wartościami projektowymi przyspieszeń. Skalowanie powinno odbywać się na akcelerogramie o zakresie częstotliwości zgodnym z zakresem zastosowanym $\mathrm{w}$ analizie ryzyka sejsmicznego. Przykładowo, analiza ryzyka sejsmicznego dla regionu LGOM wykonywana została dla akcelerogramów zawierających fale o maksymalnej częstotliwości $10 \mathrm{~Hz}$ (Lasocki, 2004).

Modelowanie dynamicznej odpowiedzi obiektów posadowionych na warstwie odkształcalnego podłoża o znacznej miąższości wymaga identyfikacji wymuszenia sejsmicznego działającego w spągu tej warstwy, a którego skutki są rejestrowane przez powierzchniowe stacje sejsmiczne (rys. 8). Realizuje się to metodą tzw. dekonwolucji sygnału, która uwzględnia wpływ warstwy gruntu na widmo zarejestrowanych na powierzchni terenu przyspieszeń (Kramer, 1996). Dekonwolucji sygnału najczęściej dokonuje się dla reprezentatywnego profilu geotechnicznego (1D) przy założeniu ekwiwalentnie liniowo sprężystego modelu gruntu np. programem SHAKE
(Ordóñez, 2011). W przypadku prowadzenia obliczeń mających na celu odtworzenie pracy obiektu podczas zarejestrowanego na obiekcie wstrząsu, procedurę dekonwolucji warto wykonać na bazie modelu dyskretnego obiektu z uwzględnieniem przestrzennie zmiennych warunków geotechnicznych i rozkładu naprężeń $\mathrm{w}$ podłożu wynikających $\mathrm{z}$ istniejącego obiektu.

$\mathrm{W}$ przedstawionej procedurze wyznaczania warunku brzegowego $a_{b x}(t)$ konieczne jest obciążenie modelu sygnałem testowym. Na podstawie widma zadanego obciążenia i reakcji modelu wyznaczana jest funkcja transmitancji modelu $H$, która zawiera informację o amplifikacji przez model fal o poszczególnych częstotliwościach. Szersze omówienie zagadnienia dekonwolucji wraz $\mathrm{z}$ analizą wpływu zastosowanego związku konstytutywnego materiału oraz sygnału testowego na dokładność odtwarzanego sygnału przedstawiono w pracy Korzec i Świdzińskiego (2018).

\section{WYNIKI}

W poniższym rozdziale zaprezentowano przykładowe wyniki obliczeń obrazujące wpływ modyfikacji akcelerogramów, przeprowadzonych według powyższych metod, na oszacowane wartości parametrów wymuszenia dynamicznego i na ocenę stateczności zapory ziemnej. Przedstawiono również wyniki serii

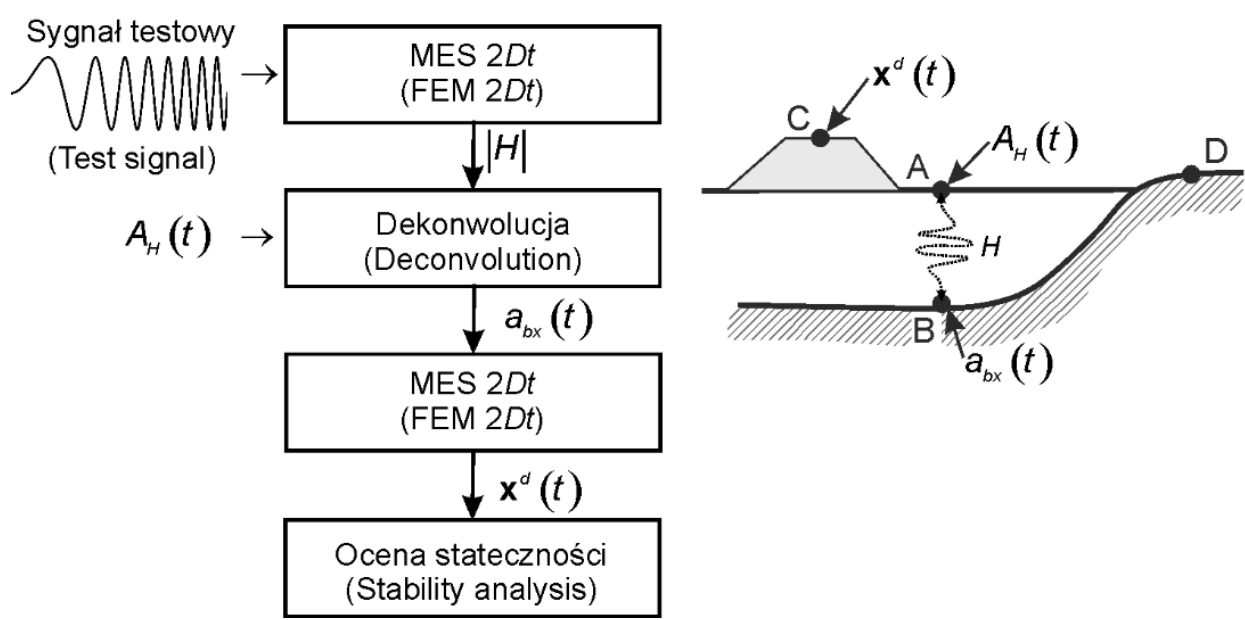

Rys. 8. Algorytm oceny stateczności zapory ziemnej obciążonej sejsmicznie posadowionej na odkształcalnym podłożu

Fig. 8. Procedure for stability analysis of earth dam on deformable soil layer subjected to seismic loading 
Korzec, A., Świdziński, W. (2018). Wybór i przygotowanie rejestracji zdarzeń sejsmicznych do modelowania numerycznego reakcji zapór ziemnych obciążonych sejsmicznie. Acta Sci. Pol. Architectura, 17 (2), 53-63. doi: 10.22630/ASPA.2018.17.2.14

analiz stateczności zapory poddanej wymuszeniom sejsmicznym o znanych parametrach, których celem było wskazanie parametru stanowiącego kryterium wyboru akcelerogramu.
W pierwszej kolejności przedstawiono wpływ szumów zawartych w sygnale na przebiegi prędkości i przemieszczeń. Porównanie tych przebiegów dla trzęsienia ziemi zarejestrowanego w Kozani w Grecji

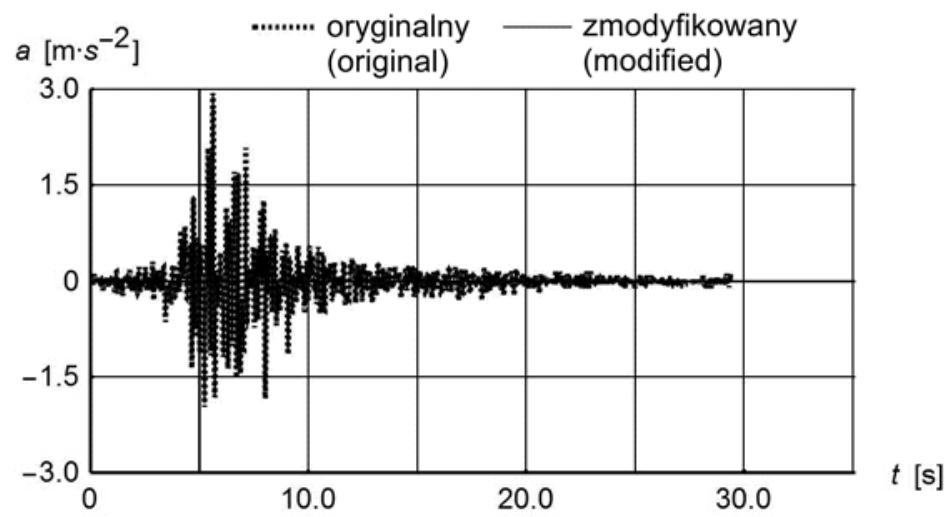

b

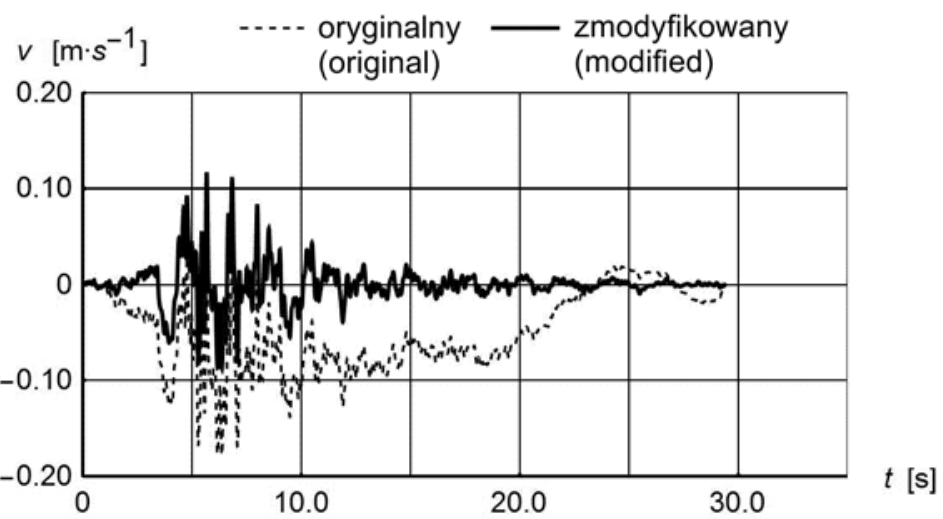

c

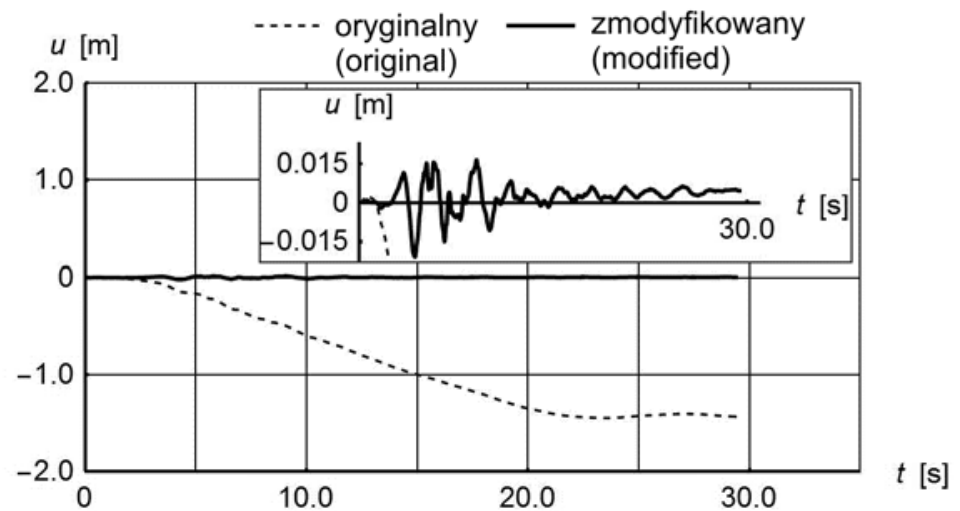

Rys. 9. Porównanie przebiegów przyspieszeń (a), prędkości (b) i przemieszczeń (c) w czasie obliczonych dla oryginalnego i zmodyfikowanego przebiegu przyspieszeń zarejestrowanego podczas trzęsienia ziemi Kozani 1995 (Grecja) ( $P G A$ przeskalowane $0,3 \mathrm{~g}$ )

Fig. 9. Comparison of the acceleration (a), velocity (b) and displacement (c) time-histories of original and modified record of Kozani 1995 (Greece) earthquake ( $P G A$ scaled to $0.3 \mathrm{~g}$ ) 
Korzec, A., Świdziński, W. (2018). Wybór i przygotowanie rejestracji zdarzeń sejsmicznych do modelowania numerycznego reakcji zapór ziemnych obciążonych sejsmicznie. Acta Sci. Pol. Architectura, 17 (2), 53-63. doi: 10.22630/ASPA.2018.17.2.14

przed modyfikacją i po niej przedstawiono na rysunku 9. Warto zauważyć, iż przed modyfikacją przebieg przemieszczeń w czasie nie miał w ogóle charakteru ruchu drgającego, a szczytowa wartość przemieszczenia wynosiła $1,45 \mathrm{~m}$. Zastosowane modyfikacje w postaci eliminacji trendu wielomianem $\mathrm{V}$ stopnia oraz usunięcie częstotliwości powyżej $25 \mathrm{~Hz}$ pozwoliły na wyznaczenie poprawnych przebiegów prędkości i przemieszczeń. Szczytowe wartości tych przebiegów wyniosły odpowiednio $0,117 \mathrm{~m} \cdot \mathrm{s}^{-1}$ i $0,021 \mathrm{~m}$. Obliczono, że wyznaczona wartość $P G V$ przed modyfikacją była o $52 \%$ zawyżona, co w znacznym stopniu fałszowałoby dokonywany wybór sygnałów obliczeniowych.

Poniżej przedstawiono wyniki serii analiz przeprowadzonych metodą Newmarka, dotyczących stateczności uproszczonego modelu zapory ziemnej poddanej dwóm typom obciążeń: sejsmicznych i parasejsmicznych. Celem tych symulacji było wy- znaczenie parametru pozwalającego na ograniczenia liczby wytypowanych akcelerogramów z zastosowaniem opisanej wyżej metodyki. Obliczenia prowadzono dla grupy akcelerogramów zarejestrowanych blisko epicentrów wstrząsu parasejsmicznego (oznaczonych jako LGOM) oraz blisko epicentrów naturalnych trzęsień ziemi zarejestrowanych na terenie Europy (oznaczonych jako ESD10km). Wszystkie akcelerogramy przeskalowano do wartości $P G A$ równej $0,3 \mathrm{~g}$, a znak akcelerogramów dobrano tak, aby skutkował największą wartością przemieszczenia trwałego $(D)$, które jest miara stateczności. Stwierdzono, że intensywność Ariasa akcelerogramów w najbardziej niezawodny sposób wskazuje przebiegi przyspieszeń skutkujące największą wartością trwałych przemieszczeń skumulowaną podczas wstrząsu (rys. 10). Pojedyncza informacja dotycząca dominującej częstotliwości, czasu trwania intensywnej fazy wstrząsu jest w zasadzie bezużyteczna. W przypad-
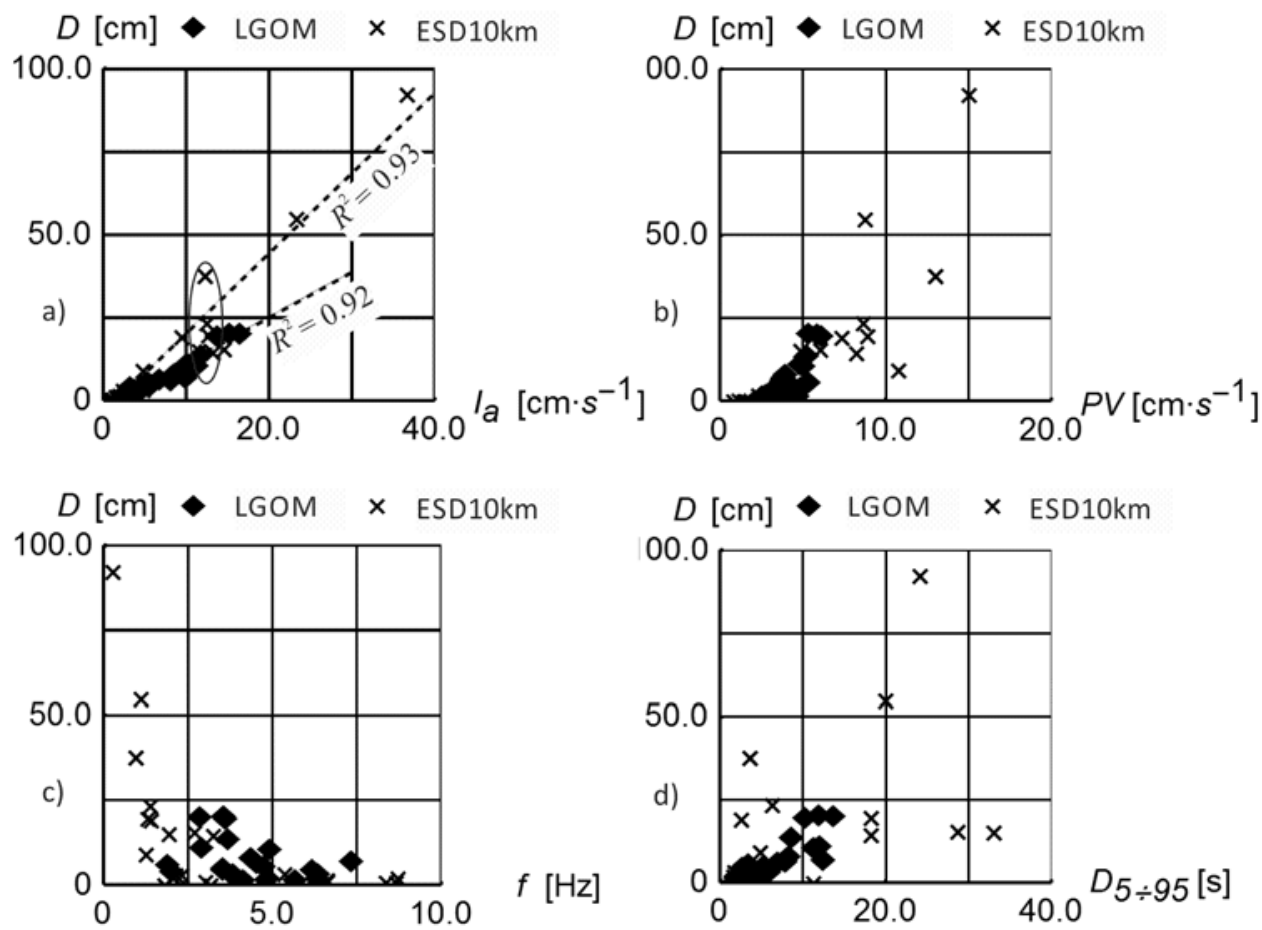

Rys. 10. Wartości trwałych przemieszczeń skumulowane podczas wstrząsów parasejsmicznych i sejsmicznych w funkcji intensywności Ariasa $-I_{a}(\mathrm{a})$, szczytowej wartości prędkości - $P G V(\mathrm{~b})$, dominującej częstotliwości - $f_{I}(\mathrm{c})$ i czasu trwania $-D_{5 \div 95}$ analizowanych sygnałów (d)

Fig. 10. Permanent deformations accumulated during paraseismic and seismic events with respect to Arias intensity $-I_{a}$ (a), peak ground velocity $-P G V(\mathrm{~b})$, predominant frequency $-f_{I}(\mathrm{c})$ and duration of strong motion $-D_{5 \div 95}$ of the signals $(\mathrm{d})$ 
Korzec, A., Świdziński, W. (2018). Wybór i przygotowanie rejestracji zdarzeń sejsmicznych do modelowania numerycznego reakcji zapór ziemnych obciążonych sejsmicznie. Acta Sci. Pol. Architectura, 17 (2), 53-63. doi: 10.22630/ASPA.2018.17.2.14

ku analizy akcelerogramów o zbliżonej intensywności Ariasa $\left(I_{a}\right)$, to szczytowa wartość prędkości $P V$ wskazuje najbardziej niekorzystne obciążenie. Przykładowe wartości $(P V)$ dla analizowanych sygnałów o $I_{a}$ wynoszącym około $13 \mathrm{~cm} \cdot \mathrm{s}^{-1}$, wynosiły 6,$2 ; 8,7$ i $13,1 \mathrm{~cm} \cdot \mathrm{s}^{-1}$ i spowodowały przemieszczenia trwałe odpowiednio 19,8; 23,7 i $38 \mathrm{~cm}$ (rys. 10a).

Procedura dekonwolucji wymaga dużej wiedzy i nakładów obliczeniowych, dlatego podjęto próbę oceny jej wpływu na wynik trwałych przemieszczeń obliczonych zmodyfikowaną metodą Newmarka. Obliczenia przeprowadzono dla modelu zapory utrzymującej nawodnione odpady poflotacyjne, obciążonej sygnałami parasejsmicznymi przeskalowanymi do niespotykanej na tym terenie wartości $P G A$ równej $0,5 \mathrm{~g}$. Pola naprężeń statycznych i powstałych na skutek wymuszenia dynamicznego obliczono w programie GeoStudio 2007 z zastosowaniem modelu ekwiwalentnie liniowo sprężystego. Dekonwolucję sygnałów (rys. 8), przeprowadzono z zastosowaniem sygnału typu linear chirp o amplitudzie $0,3 \mathrm{~g}$ i maksymalnej częstotliwości $10 \mathrm{~Hz}$. Zaobserwowano, że większość sygnałów po dekonwolucji ma dużo mniejsze szczytowe wartości przyspieszeń, a dominujące częstotliwości ulegają podwyższeniu. Stwierdzono również, że dla warunku brzegowego w postaci sygnałów zmierzonych na powierzchni terenu o założonej szczytowej wartości przyspieszeń otrzymano trwałe przemieszczenia równe $66,7 \mathrm{~cm}$, w przypadku sygnału zdekonwoluowanego nie stwierdzono zaś trwałych przemieszczeń dla żadnego $\mathrm{z}$ analizowanych mechanizmów zniszczenia (rys. 11).

\section{PODSUMOWANIE}

Artykuł poświecono zagadnieniom związanym $\mathrm{z}$ wyborem i odpowiednim przygotowaniem szeregu czasowego przyspieszeń modelującego obciążenie sejsmiczne zapór ziemnych. Wykazano, że intensywność Ariasa, która uwzględnia widmo amplitudowe akcelerogramów, jest dobrym kryterium wyboru najniekorzystniejszych akcelerogramów obliczeniowych, a uzupełniającym kryterium może być szczytowa wartość prędkości. Przedstawiono metody modyfikacji akcelerogramów i ich parametry w celu wyznaczenia poprawnego warunku brzegowego. Wskazano metode eliminacji trendu wielomianem V stopnia, jako skuteczną metodę eliminacji szumów długookresowych. Stwierdzono również, że przeprowadzenie pasmowoprzepustowej filtracji sygnału nie zawsze pozwala uzyskać oscylacyjną postać przebiegów prędkości i przemieszczeń.

Analizy numeryczne stateczności wybranej zapory ziemnej obciążonej silnym wstrząsem parasejsmicznym pokazały, że z uwagi na amplifikację fal o niskich częstotliwościach, a zarazem thumienie fal o wyższych częstotliwościach przez warstwę podłoża gruntowego, na którym spoczywa zapora ziemna, ocena jej

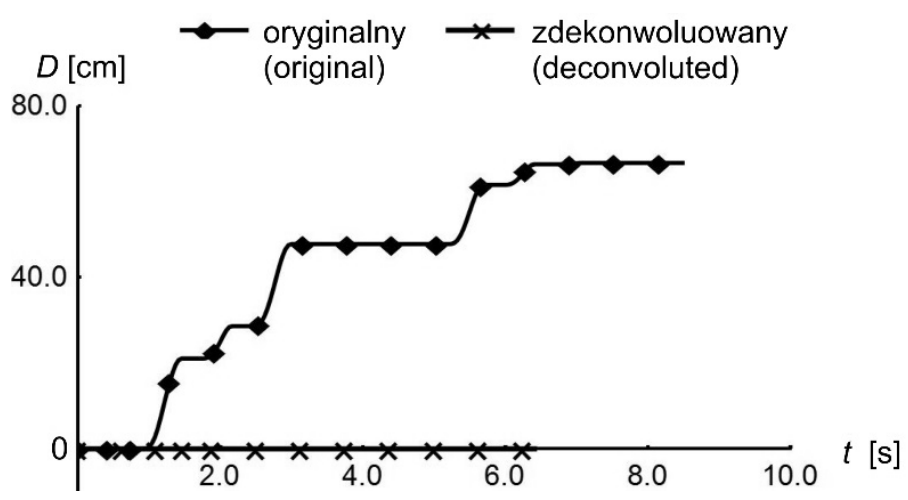

Rys. 11. Porównanie trwałych przemieszczeń obliczonych dla sygnału parasejsmicznego o szczytowej wartości przyspieszeń $0,5 \mathrm{~g}$ i sygnału zdekonwoluowanego do podstawy modelu

Fig. 11. Comparison of permanent deformations accumulated during paraseismic event with $P G A$ equal to $0.5 g$ and the deconvoluted accelerogram 
Korzec, A., Świdziński, W. (2018). Wybór i przygotowanie rejestracji zdarzeń sejsmicznych do modelowania numerycznego reakcji zapór ziemnych obciążonych sejsmicznie. Acta Sci. Pol. Architectura, 17 (2), 53-63. doi: 10.22630/ASPA.2018.17.2.14

stateczności przeprowadzona dla warunku brzegowego w postaci sygnałów zmierzonych na powierzchni terenu (bez ich dekonwolucji) jest po stronie bezpiecznej.

\section{PIŚMIENNICTWO}

Ambraseys, N. N., Smit, P., Douglas, J., Margaris, B., Sigbjornsson, R., Olafsson, S., Suhadolc, P. i Costa, G. (2004). Internet site for European strong-motion data. Bollettino di Geofisica Teoretica ed Applicata, 45(3), 113-129. doi: 10.1.1.707.8981

Arias, A. (1970). A measure of earthquake intensity. W R. J. Hansen (red.), Seismic Design for Nuclear Power Plants (strony 438-483). Cambridge, MA: MIT Press.

Bommer, J. J. i Acevedo, A. B. (2004). The use of real earthquake accelerograms as input to dynamic analysis. Journal of Earthquake Engineering, 8(1), 41-91. doi: 10.1080/13632460409350521

Boore, D. M. i Bommer, J. J. (2005). Processing of strongmotion accelerograms: needs, options and consequences. Soil Dynamics and Earthquake Engineering, 25, 93-115. doi: 10.1016/j. soildyn.2004.10.007

EC8 (2005): Eurocode 8. Design of structures for earthquake resistance.

ICOLD (2016). Selecting seismic parameters for large dams. Guidelines (Revision of Bulletin 72). Bulletin 148.

Jamiolkowski, M., Carrier, W. D., Chandler, R. J., Hoeh, K., Świerczyński, W. i Wolski, W. (2010). The geotechnical problems of the second world largest copper tailings pond at Zelazny Most, Poland. Geotechnical Engineering Journal of the SEAGS \& AGSSEA, 41(1), 1-15.
Korzec, A. (2016). Wptyw sktadowej pionowej przyspieszenia wywołanego obciążeniem sejsmicznym na stateczność zapór ziemnych (rozprawa doktorska). Warszawa: PAN.

Korzec, A. i Świdziński, W. (2018). Dynamic response of Zelazny Most tailings dam to mining induced extreme seismic event occurred in 2016. LXIV Konferencja Naukowa w Krynicy Zdrój [przyjęte do druku].

Kramer, S. L. (1996). Geotechnical Earthquake Engineering. Upper Saddle River, NJ: Prentice-Hall.

Lasocki, S. (2004). Prognoza granicznych wielkości drgań gruntu na obiektach składowiska Żelazny Most dla okresu 2003-2028. XXVII Zimowa Szkoła Mechaniki Górotworu.

Lowrie, W. (2007). Fundamentals of Geophysics. Cambridge: Cambridge University Press.

Świdziński, W. i Korzec, A. (2015). Ocena dynamicznej odpowiedzi zapór ziemnych w świetle aktualnych unormowań. Inżynieria Morska i Geotechnika, 3, 489-493.

Ordóñez, G. A. (2011). SHAKE2000. A computer program for the 1-D analysis of geotechnical earthquake engineering problems. User's manual. Washington USA: GeoMotions.

Srbulov, M. (2008). Geotechnical Earthquake Engineering. Simplified Analyses with Case Studies and Examples. Springer.

Trifunac, M. D. i Brady, A. G. (1975). A study on the duration of strong earthquake ground motion. Bulletin of the Seismological Society of America, 65(3), 581-626.

Zembaty, Z. (2004). Rockburst induced ground motion a comparative study. Soil Dynamics and Earthquake Engineering, 24, 11-23. doi: 10.1016/j.soildyn.2003.10.001

\title{
SELECTION AND PREPARATION OF STRONG-MOTION RECORDS FOR DYNAMIC RESPONSE ANALYSIS OF SEISMICALLY LOADED EARTH DAMS
}

\begin{abstract}
In the paper the way of selection and processing of strong-motion records used in stability analysis of seismically loaded earth dams has been presented. Moreover the selection methodology has been supplemented by Arias intensity criterion which allows to determine the accelerogram giving the highest value of permanent displacement of the dam. It was also shown that in case of analyzing the signals with similar Arias intensity, the peak ground velocity is a decisive criterion. The paper is also focused on processing of strong-motion records which is essential to achieve reliable stability assessment. The influence of noise on velocity and displacement time-histories, and thus on calculation results has been shown. Moreover, the effect of signal deconvolution on stability assessment of the earth dam has been analyzed.
\end{abstract}

Key words: dynamic analysis, earthquake, strong-motion records, stability analysis, deconvolution, signal analysis 